INVITED REVIEW ARTICLE

放射線肺臓炎：放射線腫瘍医の視点から

\title{
辻野佳世子1
}

\section{Radiation Pneumonitis: from the Viewpoint of a Radiation Oncologist}

Kayoko Tsujino1

${ }^{1}$ Department of Radiation Oncology, Hyogo Cancer Center, Japan.

ABSTRACT - Radiation pneumonitis (RP) is one of the most common dose-limiting adverse effects in the treatment of thoracic malignancies, including lung cancer. In cases of concurrent chemoradiotherapy for locally advanced lung cancer, symptomatic RP occurs in $5-50 \%$ of all patients and becomes severe or even fatal in some cases. Moreover, recently many patients also receive molecular targeted agents and/or immune checkpoint inhibitors. Thus, we should pay more attention to the occurrence of RP and the accurate prediction and prevention of severe RP is essential for safe and efficacious treatment. This manuscript provides an overview of the definition, classification, etiology, symptoms, diagnosis, grading system, risk factors, and management of RP. In particular, radiotherapy-related risk factors, such as dose-volume parameters, and the methods for the prediction and prevention using these factors are reviewed in detail from the perspective of radiation oncologist.

(JJLC. 2019;59:333-341)

KEY WORDS — Radiation pneumonitis, Radiation induced lung injury, Radiotherapy, Toxicity, Lung cancer

Corresponding author: Kayoko Tsujino.

要旨——肺癌など胸部腫瘍に対する放射線治療におい

て，その遂行を制限する有害事象の代表が放射線肺臓炎 (radiation pneumonitis：RP)である. 局所進行肺癌に対 する標準治療である化学放射線同時併用療法においては 有症状の RP の発症頻度が 5 50\% と高く，その一部は 重症となり，1〜2\% は致死的な肺臓炎を発症している. また近年は化学療法に加えて分子標的薬剤の使用例も増 加し, さらに免疫チェックポイント阻害薬による地固め 療法の有用性が示され, 一層 RP に対する注意が必要と
なっている. 本稿では RP の全般, すなわち定義, 分類, 発症機序, 症状, 診断, グレード診断, リスク因子, 管 理治療法について概論した．特にリスク因子と発症予測 法・予防法について, 放射線治療線量容積関連因子とそ れに基づく放射線治療適応・治療計画時線量制約考慮点 など，放射線腫瘍医の視点を中心として現在までの知見 を総括した。

索引用語——放射線肺臓炎, 放射線性肺障害, 放射線治

療, 有害事象, 肺癌

\section{はじめに}

肺癌・食道癌・縦隔腫瘍などの胸部腫瘍に対する放射 線治療は重要な治療モダリティーのひとつであるが, そ の遂行を制限する有害事象の代表が放射線肺臓炎（radiation pneumonitis：RP）である。多くは自然経過で収 束し臨床的な問題は少ないが, 一部は重篤となり QOL を低下させ，稀ではあるが照射野外に広がり致死的とな ることがある. 局所進行肺癌に対する標準治療である化
学放射線同時併用療法 (concurrent chemoradiotherapy：CCRT）においては, 有症状の RP の発症頻度が 5〜 50\% と高く, その一部は重症となり, 1〜 2\% は致死的 な肺臓炎を発症している。 また近年は化学療法に加えて 分子標的薬剤の使用例も増加し, さらに免疫チェックポ イント阻害薬併用の有用性が示され, 一層 RP に対する 注意が必要となっている。

本稿では RP の全般について概論するとともに, 特に そのリスク因子と発症予測法・予防法について, 放射線 


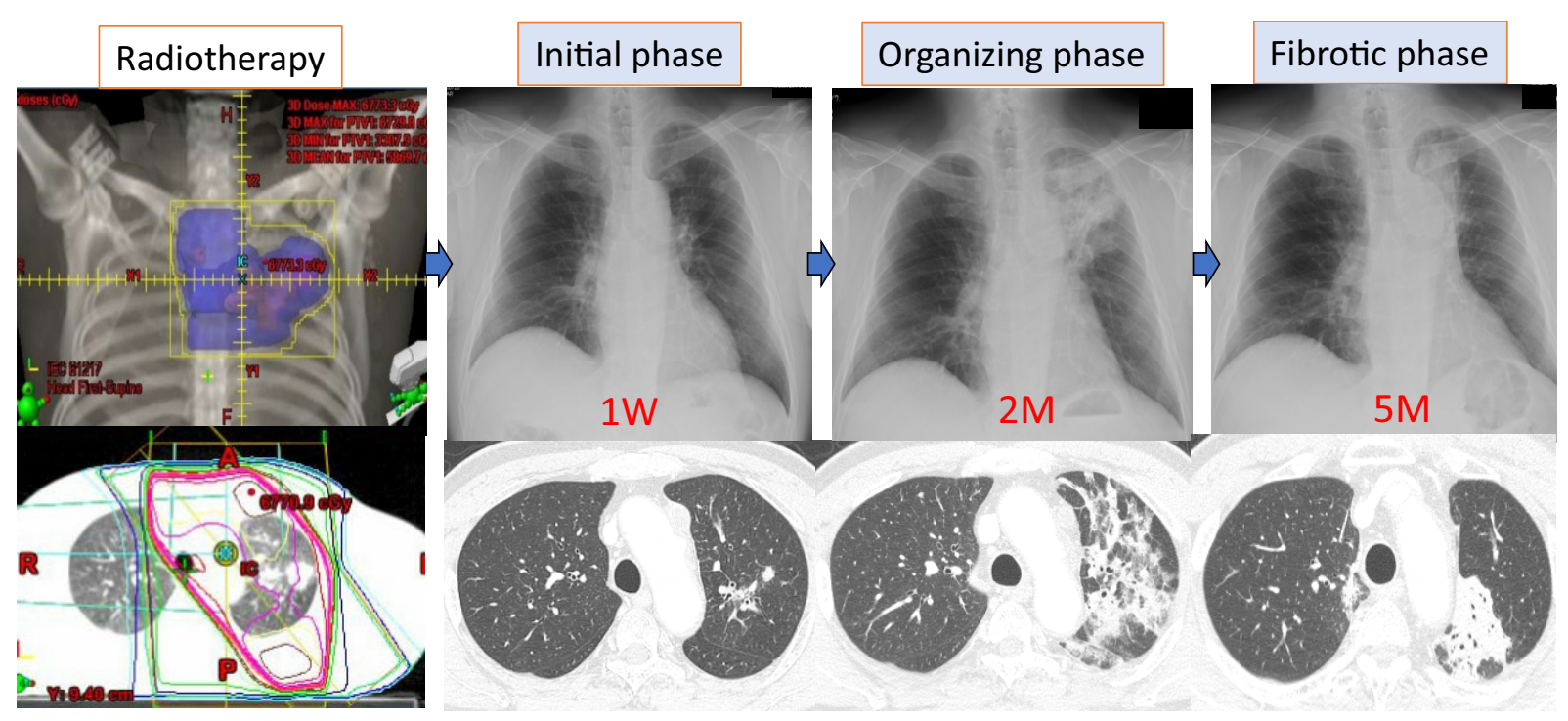

Figure 1. Typical chest X-ray and CT findings of radiation pneumonitis.

治療関連因子とそれに基づく放射線治療適応・治療計画 時の考虑点など，放射線腫湯医の視点を中心として現在 までの知見を総括する.

\section{放射線肺臓炎とは}

\section{定義・分類}

放射線治療に起因する肺障害は, 放射線性肺障害（radiation induced lung injury : RILD) と総称され, 急性期 から亜急性期（照射中後期～終了後半年程度）に発症す る RP と，それに引き続く晚期 (照射終了半年以降)の放 射線肺線維症（radiation fibrosis）に分類される. 1,2 重症 化や致死的な転帰となるなど臨床的に問題となるものは 主に前者であり，本稿に抢いても主に扱う．

さらに RP は, Classic RP と Sporadic RP に分類され ることがある. ${ }^{1}$ Classic RP とは一般的にみられる放射 線照射体積内から出現するものであるのに対し, Sporadic RP とは hypersensitivity pneumonitis とも称さ れ, 照射野外に淡く広がる陰影を呈し, 気管支肺胞洗浄 液 (bronchoalveolar lavage fluid：BALF）では両肺から $\mathrm{CD} 4{ }^{+} \mathrm{T}$ 細胞を主とするリンパ球増多を認めるもので, 乳癌症例に報告が多いが, 肺癌でもみられることがある. 本稿に捛いては主に前者を扱う。

\section{発症機序}

Classic RP の発症機序については, early（latent） phase, intermediate (acute pneumonitis) phase, late (pulmonary fibrosis) phase の 3 つの発症段階が提唱さ れている. ${ }^{2-4}$ Early (latent) phase（照射開始直後〜数週 間）は，臨床的変化はみられないが細胞内での変化が始 まっている時期である. 電離放射線が肺に照射されると,
直後よりフリーラジカルが形成され, 毛細血管透過性杂 進による肺胞間質の浮腫, I 型肺胞上皮細胞の減少・II 型肺胞上皮細胞障害によるサーファクタントの肺胞内へ の流出, 種々のサイトカインの放出による炎症性細胞の 肺胞への集積が始まる. Intermediate（acute pneumonitis) phase（数週〜数か月程度）になると血管内皮細胞障 害による毛細血管閉塞, リンパ球・形質細胞などの炎症 性細胞の浸潤による肺胞隔壁の肥厚・肺胞の狭小化がみ られ, 臨床的な急性から亜急性期肺臟炎の所見・症状を 呈する. その後, late (pulmonary fibrosis) phase（数か 月以降)になると毛細管の脱落, collagen の沈着による肺 胞隔壁の肥厚と肺胞腔の消失がみられ, 線維化が完成す る。

\section{症状・診断・臨床経過}

軽度の場合は無症状であることも多いが, 初期症状と しては乾燥咳・息切れ・胸痛・微熱などの非典型的な呼 吸器症状がみられる。発症時期が特徽的で照射直後や 5〜6か月程度経過してから発症する場合もあるが, 多く は照射終了後 1 3 か月程度で発症する. 理学的所見とし ては聴診での crackle と pleural rub が照射野付近で聴 取される. 生化学的検查では中等度の白血球, LDH, CRP 増加, KL-6, SP-D 増加などを認め, 鑑別診断のために $\mathrm{BAL}$ が行われることもあるが, RP に特異的な所見はな い. 5

診断の要となるのは胸部 X 線などの画像診断で特に CT 所見が特徵的であり, 前述の発症機序の段階に応じ た所見を示す (Figure 1)。まず発症初期 (Initial phase) では照射野内の肺にスリガラス影 (ground glass attenuation), 網状影などの間質陰影が出現する. 近年の high- 
Table 1. Comparison of Radiation Pneumonitis Grading Systems

\begin{tabular}{|c|c|c|c|c|c|}
\hline Grading system & Grade 1 & Grade 2 & Grade 3 & Grade 4 & Grade 5 \\
\hline $\begin{array}{l}\text { RTOG } \cdot \\
\text { EORTC } \\
\text { (LENT-SOMA) }\end{array}$ & $\begin{array}{l}\text { Asymptomatic or mild } \\
\text { symptoms (dry cough), with } \\
\text { radiographic findings }\end{array}$ & $\begin{array}{l}\text { Moderately symptom- } \\
\text { atic (severe cough, } \\
\text { fever) }\end{array}$ & $\begin{array}{l}\text { Severely symptom- } \\
\text { atic }\end{array}$ & $\begin{array}{l}\text { Severe respiratory insuffi- } \\
\text { ciency; continuous oxygen/ } \\
\text { assisted ventilation }\end{array}$ & Death \\
\hline SWOG & $\begin{array}{l}\text { Asymptomatic or symptoms } \\
\text { not requiring steroids, with } \\
\text { radiographic findings }\end{array}$ & $\begin{array}{l}\text { Initiation of increase } \\
\text { in steroids required }\end{array}$ & $\mathrm{O}_{2}$ required & $\begin{array}{l}\text { Assisted ventilation re- } \\
\text { quired }\end{array}$ & Death \\
\hline $\begin{array}{l}\text { NCI-CTC } \\
\text { ver.2 }\end{array}$ & $\begin{array}{l}\text { Radiographic changes but } \\
\text { asymptomatic or symptoms } \\
\text { not requiring steroids }\end{array}$ & $\begin{array}{l}\text { Radiographic changes } \\
\text { and requiring steroids } \\
\text { or diuretics }\end{array}$ & $\begin{array}{l}\text { Radiographic } \\
\text { changes; } \mathrm{O}_{2} \\
\text { required }\end{array}$ & $\begin{array}{l}\text { Radiographic changes; } \\
\text { assisted ventilation required }\end{array}$ & Death \\
\hline $\begin{array}{l}\text { NCI-CTCAE } \\
\text { ver.3 }\end{array}$ & $\begin{array}{l}\text { Asymptomatic; radiographic } \\
\text { findings only }\end{array}$ & $\begin{array}{l}\text { Symptomatic; not } \\
\text { interfering with ADL }\end{array}$ & $\begin{array}{l}\text { Symptomatic; } \\
\text { interfering with } \\
\mathrm{ADL} \mathrm{O}_{2} \text { indicated }\end{array}$ & $\begin{array}{l}\text { Life-threatening; ventilation } \\
\text { support indicated }\end{array}$ & Death \\
\hline $\begin{array}{l}\text { NCI-CTCAE } \\
\text { ver. } 4 \text {, ver. } 5\end{array}$ & $\begin{array}{l}\text { Asymptomatic; clinical or } \\
\text { diagnostic observations only; } \\
\text { intervention not indicated }\end{array}$ & $\begin{array}{l}\text { Symptomatic; medical } \\
\text { intervention indicated; } \\
\text { limiting instrumental } \\
\text { ADL }\end{array}$ & $\begin{array}{l}\text { Severe symptoms; } \\
\text { limiting self-care } \\
\text { ADL; } \mathrm{O}_{2} \text { indicated }\end{array}$ & $\begin{array}{l}\text { Life-threatening respiratory } \\
\text { compromise; urgent inter- } \\
\text { vention indicated (e.g., } \\
\text { tracheotomy or intubation) }\end{array}$ & Death \\
\hline
\end{tabular}

resolution CT (HRCT) で詳細に検討すると, ある程度以 上の線量が投与された場合ほとんどの症例で軽度の陰影 は認められる。この時期にはまだ無症状から軽度の症状 であることが多い.ついで器質化期 (Organizing phase) になると，比較的境界明瞭な濃度上昇 (patchy consolidation）が放射線照射野と一致して肺区域や肺葉などの解 剖学的境界と無関係に広がってくる。この程度が強いと 種々の呼吸器症状の出現をみる。この時期を過ぎると線 維化期（Fibrotic phase）となり, 線状の㓔痕化や濃い濃 度上昇 (dense consolidation), 肺容積の減少を放射線照 射範囲に一致して認めるようになる。この時期には急性 期の症状は消失し安定するが, 容積低下が著明な場合呼 吸機能が低下する場合もある。特に診断に迷う発現初期 には，初期のスリガラス影が照射範囲内から出現してい るか否かが診断の鍵となり, 治療計画 CT 上の線量分布 図との対比が重要である. 鑑別診断としては感染症, 癌 性リンパ管症・腫瘍浸潤, 薬剂性肺炎, その他の間質性 肺炎，心不全などがある。

臨床経過としては, 多くは経過観察で次第に肺線維症 に移行し安定するが, 症状が強い場合はステロイドを中 心とする治療を要し, 時に照射野外に広がって重症化し, 稀に致死的となることがある.

\section{グレード分類}

$\mathrm{RP}$ のグレード分類として, 以前は放射線障害に特化 した RTOG 分類, SWOG 分類などが使用されていたが, 最近では NCI-CTCAE 分類が主に用いられており, 他の 原因の肺臓炎と共通である。 NCI-CTCAE 分類において も versionによって定義が異なり，過去の文献を参照す る際にはどの分類が用いられているかに注意を要する. 各分類の比較を Table 1 に示す. 現在用いられている NCI-CTCAE ver.4 および ver.5においてはグレード 1 とグレード 2 , グレード 2 とグレード 3 の症状の解釈や
内科的治療適応に主観的要素があり, その境界がやや曖 昧である.グレード 3 以上が重症と考えられている.

\section{発症頻度}

有症状 RP (グレード 2 以上) の発症頻度としては肺癌 根治照射例で 5 50\%, 縦隔腫瘍で 5〜 10\%, 乳癌では 1 $5 \%$ と報告されている. 最も懸念される致死的な RP は, 肺癌根治照射症例では $1 \sim 2 \%$ 程度の報告が多い. 3,6

\section{リスク因子と予測・予防法}

上記のように特に肺癌根治照射後にはグレード 1 まで 含めると多くの症例で発症する RPであるが, 有症状や 重症な RP を発症しやすいリスク因子が放射線治療・患 者・腫瘍など, それぞれについて報告されている.

\section{放射線治療関連因子}

放射線治療の有害事象を考える時に重要な概念として 正常組織の臓器特性があり, 一般に直列蔵器と並列臓器 に分類される，直列蔵器とは連続する subunit で構成さ れるため一部を損傷すると器官としての機能が損なわれ てしまう臓器で, 脊髄や末梢神経, 中枢気管支, 食道・ 腸管 (狭窄や穿孔について) などある。. 並列臓器とは, 多くの subunit で構成されそれぞれの subunit が並行し て同じ機能をはたしていると考えられる臓器で肺・肝・ 心膜などがある。直列臓器ではある小部分でも耐容線量 以上が投与されると有害事象が発生するが, 並列臓器で は一部が損傷されても他部位がそれを補うため, その発 症には照射線量と照射体積の両方が関与する。肺は典型 的な並列臓器とされ, RP の発症リスクについては照射 線量のみでなく特に照射野の大きさが重要である。放射 線治療における耐容線量についての古典的な基準である Emamiらの報告では, RPをエンドポイントとした TD5/5（5 年後までに 5\% の確率でその有害事象が発症 する線量) は肺の $1 / 3,2 / 3,3 / 3$ の体積の照射で各々 45, 


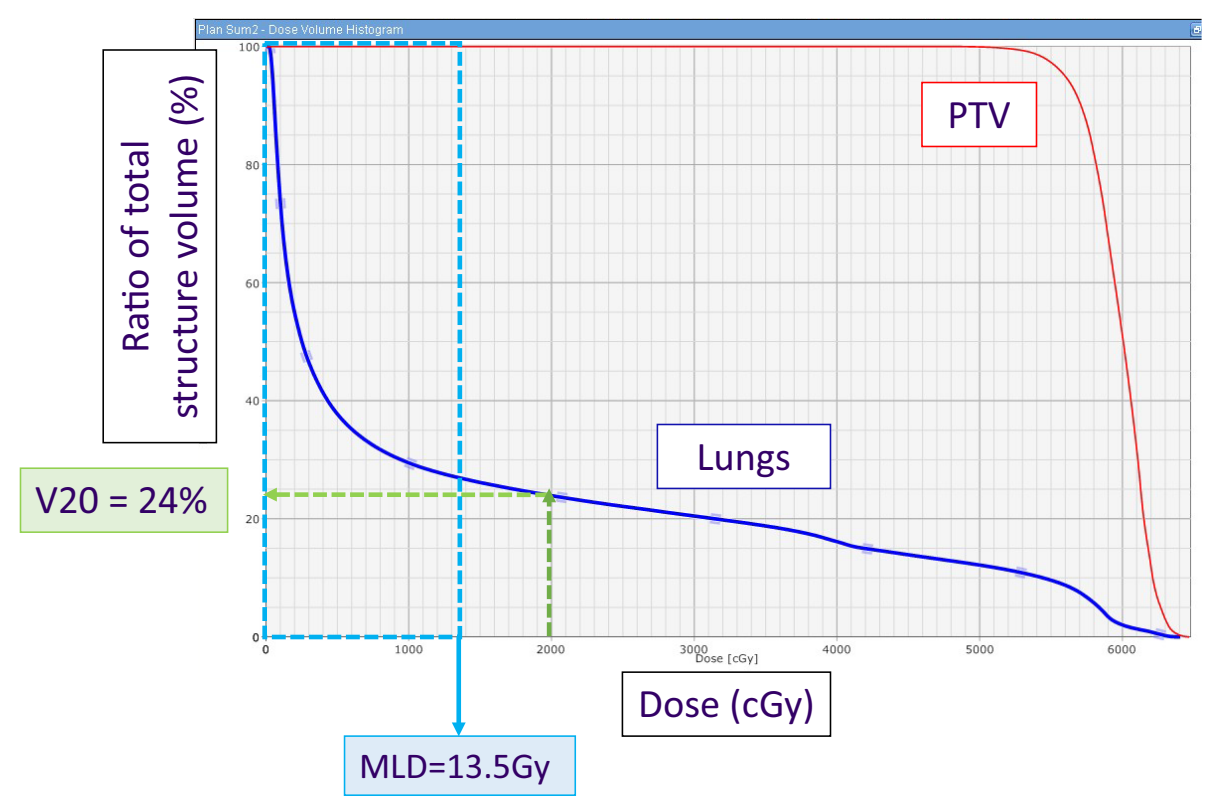

Figure 2. Example of lung DVH and DVH parameters. Lung Vx (\%) indicates the percentage of lung volume receiving a dose in excess of X Gy (e.g. V20).

30, $17.5 \mathrm{~Gy}$ とされている. 7

1990 年代に, 現在標準となっている CT に基づく三次 元放射線治療（3 dimensional conformal radiotherapy : 3D-CRT) が導入されると, 線量容積ヒストグラム (dosevolume histogram : DVH) により正確な線量と容積の関 係を示すことが可能となり，DVH から導かれる種々の パラメータと $\mathrm{RP}$ 発症の相関性が検討されてきた. パラ メータとしては, DVHに生物学的要素も考慮された NTCP (normal tissue complication probability) や平均肺 線量 (mean lung dose : MLD) (Gy), Vdose (\%)（ある線 量以上照射される肺容積の全肺容積に対する割合）など がある (Figure 2). 当初は NTCP や MLD の報告が主で あったが, 1999 年に Graham らは 99 例の非小細胞肺癌 放射線治療例（うち $58 \%$ 照射単独）と RTOG グレード 2 以上の RP の発症に対するリスク因子を検討し, 両肺の V20（20 Gy 以上照射される肺容積の全肺容積に対する 割合)が< $22 \% ， 22 \sim 31 \% ， 32 \sim 40 \% ，>40 \%$ 以上での発 症率がそれぞれ $0,16,18$ (1 例致死的)，52(3 例致死的)\% であり, 多変量解析で V 20 のみが有意な相関因子であっ たと報告した8 (Figure 3A). また我々は当院での CCRT （通常分割照射 $60 \mathrm{~Gy}$ 中心）施行 71 例について種々の因 子を解析し, 同様に V 20 のみが多変量解析で NCI-CTC ver. 2 グレード 2 以上の RP の発症に有意な相関性を認 め, V20 が $31 \%$ 以上の場合の発症率が $85 \%$ と高く, また うち 2 例で死亡例が発生していたと報告した9 (Figure $3 \mathrm{~B}) .2010$ 年には米国腫瘍放射線学会（ASTRO）の QUANTEC project 70 以上の報告の review が行わ
れ, 肺癌における有症状 RP の発症はVdose, MLD との 関連が高いことが確認され，V20 值および MLD 值と有 症状 RP の発症率の関係にひとつの基準が提示された 10 (Table 2).これらのデータをもとに現在では通常分割 $60 \mathrm{~Gy} / 30$ 回程度の CCRT においては両肺の V20 を 35\% 以下, MLD を $20 \mathrm{~Gy}$ 以下にするよう放射線治療計画を 行うことが推奨されている。 ただし, 日本人データでは $\mathrm{RP}$ の発症報告が海外と比較しやや多い傾向がみられ, 日本の臨床試験のデータではV V 20 が $30 \%$ 以上 $35 \%$ 以下 の症例で致死的 RP の発症がみられたという報告11もあ るため, V20 が 30〜 35\% は治療可能であるが注意深い経 過観察が必要と考える.

また近年ではより低線量の関与も注目されている。低 線量の DVH パラメータとしてはV5（\%)の報告が多い12 が, VS5 (AVS5) (cc) (absolute volume spared from 5 $\mathrm{Gy}$ : $5 \mathrm{~Gy}$ 照射されない肺の実容積）が特に肺障害との 相関性が高かったという報告も散見される.13,14 そのた め現在ではV20 や MLDのみでなく低線量による線量 制約も考慮するよう推奨されており, NCCN で推奨され ている線量制約基準を Table 3 に示す. 放射線腫瘍医, 医 学物理士は腫瘍への治療線量を確保したうえでこれらの 正常組織の線量制約を遵守するよう治療計画を工夫し, また治療適応判断のひとつの基準としている.

もちろん総線量の違いや通常分割照射以外の線量分割 法では RP 発症リスクも異なり, 線量制約も異なってく る. 我々は限局型小細胞肺癌の標準治療のひとつとなっ ている $45 \mathrm{~Gy} / 30$ 回/3 週の加速多分割照射 + 化学療法同 
A

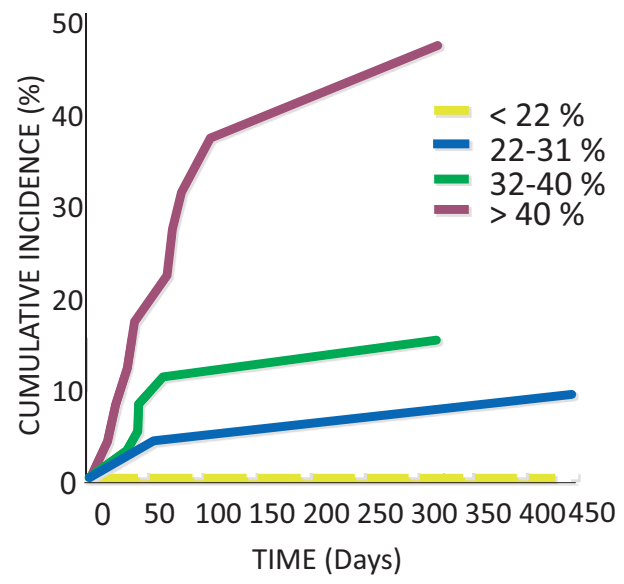

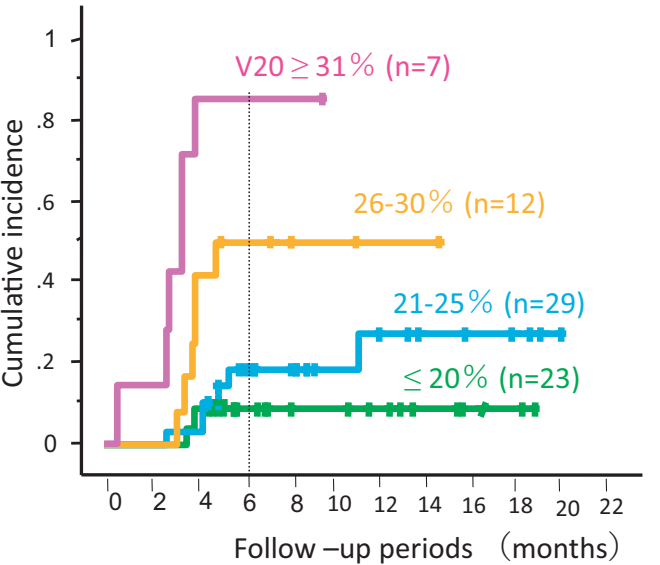

Locally advanced lung cancer $\mathrm{N}=71$, All concurrent chemoradiotherapy, Endpoint: $\geq$ G2RP (CTCAE ver.2) V20 $\leq 20 \% \quad ; 8 \%$ $21-25 \% \quad ; 18 \%$ $26-30 \% \quad ; 50 \%$ V20 $\geq 31 \% \quad ; 85 \%$

Figure 3. Cumulative incidence of grade $\geq 2 \mathrm{RP}$ according to lung V20. A: with or without chemotherapy lung cancer patients, ${ }^{8}$ B: lung cancer patients receiving concurrent chemoradiotherapy. ${ }^{9}$

Table 2. Relationship Between the DVH Parameters and the Incidence of Symptomatic RP as Determined by a QUANTEC Analysis ${ }^{10}$

\begin{tabular}{ccc}
\hline DVH parameter & Range & Symptomatic RP \\
\hline V20 & $\leq 30 \%$ & $\leq 20 \%$ \\
MLD & $7 \mathrm{~Gy}$ & $5 \%$ \\
& $13 \mathrm{~Gy}$ & $10 \%$ \\
& $20 \mathrm{~Gy}$ & $20 \%$ \\
& $24 \mathrm{~Gy}$ & $30 \%$ \\
& $27 \mathrm{~Gy}$ & $40 \%$ \\
\hline
\end{tabular}

時併用例について解析し，V20 との相関性はあるが，通 常分割照射症例よりも同じDVHパラメータ值の場合 $\mathrm{RP}$ の発症率が低いことを示し，より緩い線量制約で可 であるとした. 15

一方，放射線治療の高精度化・呼吸移動対策の発展に ともない, 強度変調放射線治療 (intensity modulated radiotherapy：IMRT) や体幹部定位放射線治療 (stereotactic body radiotherapy：SBRT）が肺癌に対しても行われ るようになり，より腫瘍に線量を集中しつつ周囲の正常 組織への線量を低減できるようになってきた。ただし，

これらの方法は多方向からの多門照射や回転照射となる ため，正常組織に対する高線量照射は低減できるが，低 線量が広範囲に広がるという特徵がある（Figure 4)。肺 に対する小範囲の高線量と広範囲の低線量のどちらがよ
Table 3. Recommended Normal Lung Dose Constraints for Conventionally Fractionated RT with Concurrent Chemotherapy for Lung Cancer (NCCN 2018)

\begin{tabular}{cc}
\hline DVH parameter & Dose constraint \\
\hline V20 & $\leq 35 \%$ \\
V5 & $\leq 65 \%$ \\
MLD & $\leq 20 \mathrm{~Gy}$ \\
\hline
\end{tabular}

りRP の発症に関与するかについては議論がある16が, 結論はいまだ不明である。しかし多門，回転照射例にお いて全肺に広がる致死的放射線肺炎発症の報告が散見さ れ, 17 広範な低線量照射の影響が示唆されている。一方 でIMRTと 3D-CRTを症例毎に選択できた臨床試験の 二次解析において, IMRT の方が有意にグレード 3 以上 の RP の発症が少なかったという報告もあり,18 現在日 本においてもその普及とともに期待が高まっている.

さらに近年陽子線や炭素線の粒子線治療を用いること により, 線量を腫瘍に集中しつつ周囲肺への低線量も低 減できることから, 治療効果の向上とともに低線量の広 がりによる RP の発症低下も期待されている。しかし最 近報告された局所進行肺癌に対する陽子線と IMRT の 前向き比較試験においては治療成績に有意差はなく，む しろ IMRTの方がややRPの発症が低い傾向であっ 


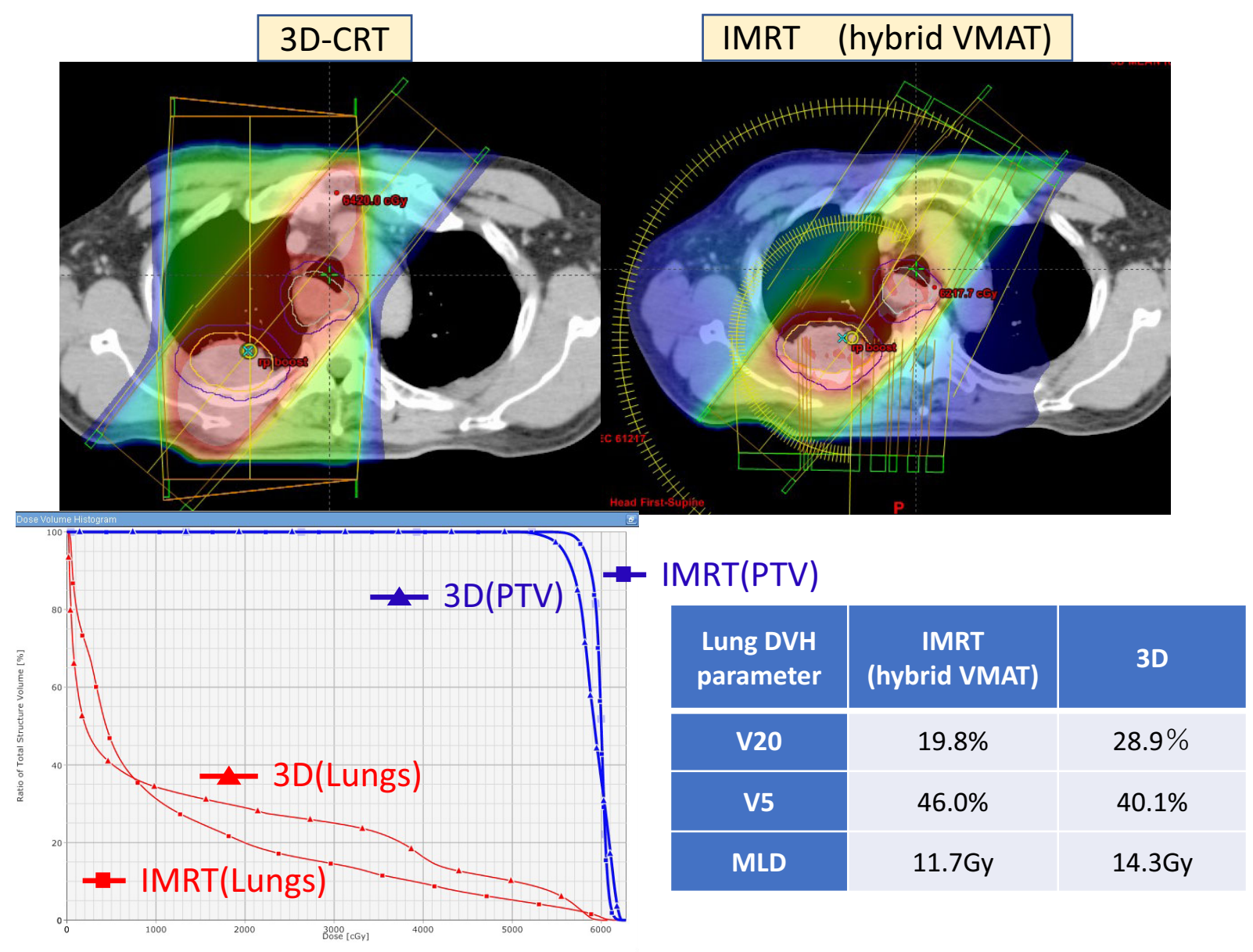

Figure 4. Comparison of the 3D-CRT and IMRT (hybrid VMAT) plans. With the IMRT plan, a lower percentage of patients receive a high dose to the lung and a higher percentage receive a low dose to the lung in comparison to the 3D-CRT plan. The conformity of the PTV (tumor) in the IMRT plan is superior to that than in the 3D-CRT plan.

た. 19

\section{患者・腫瘍・併用治療関連因子}

$\mathrm{RP}$ 発症のリスクが高い可能性があるとして報告され ている患者・腫瘍因子としては, 年齢 (高齢), 性別 (女 性)，契煙歴(両者の報告があるが，非契煙者に多いとい う報告が多い), 併存肺疾患 (間質性肺臓炎, COPD), 肺 機能不良 $\left(\mathrm{FEV} 1.0, \mathrm{FEV} 1.0 \%, \mathrm{DLCO} \%, \mathrm{PaO}_{2}\right)$, 腫瘍部位 (下葉), 腫瘍体積 (大), 病期 (進行) などがある. $2,20,21$ 放射線治療以外の併用治療因子としては, 併用化学療法 のタイミング (同時・化学療法先行の両方の報告あり)や 薬剂レジメン, 既往の肺手術歴・化学療法歴などがあ る. ${ }^{20,21}$ TGF- $\beta 1$, IL-1, IL-6, sICAM-1, KL-6, surfactant protein-A, D などの種々のサイトカインやいくつかの遺 伝子多型との関連性についても多数検討されており, 特 にTGF- $\beta 1$ との相関性が注目されている. 22

併存肺疾患の中でも特に間質性肺臓炎の合併はリスク が高いと考えられており, 胸部 X 線で明らかな高度の間 質性肺臓炎は一般に根治的胸部放射線治療の適応外であ
る. 軽度の間質性変化を有する場合は照射適応とする場 合が多いが, RP 発症リスクは高くなるため細心の注意 が必要である. 23,24

非小細胞肺癌に対し同時性化学放射線療法を施行した 国際多施設個別患者データ 836 例についてのメタアナリ シスによると, 有症状肺炎の発症率 $29.8 \%$, 致死的肺炎発 症率 $1.9 \%$ であり, 有症状肺炎の発症に関与する因子は多 変量解析で V20, 化学療法内容 (carboplatin/paclitaxel) であったことが報告された. ${ }^{6}$ 致死的肺炎の発症に関与 する因子は, 単変量解析で, 1 日線量が 2 Gy を超える, V20 高值, 腫瘍部位が下葉の 3 つであった。

最近, 局所進行非小細胞肺癌に対する同時化学放射線 療法後の地固め療法として免疫チェックポイント阻害薬 immune checkpoint inhibitor (ICI) durvalumab を投与す ることにより, 非再発生存・全生存ともに有意に延長を 認める結果が報告され, 25 標準治療に大きな変化が起き ている. ICI 単独でも間質性肺臓炎は注意すべき有害事 象であり, 胸部放射線療法との併用はそのリスクが増強 


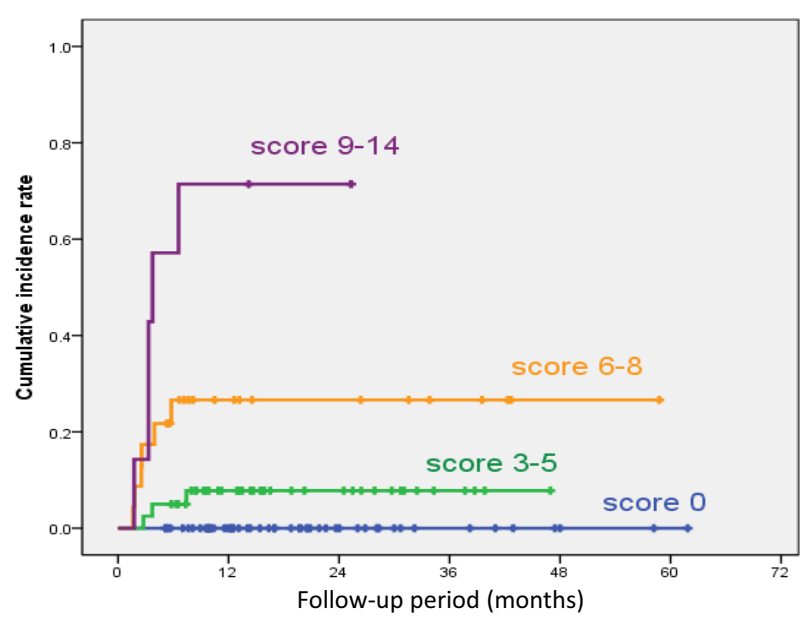

Figure 5. The incidence of severe (grade $\geq 3$ ) RP according to the predictive risk score (PRS). ${ }^{24}$

する可能性が危惧されていた。 しかしこの試験の解析で は RP を含む肺臓炎は durvalumab 群 33.9\%, プラセボ群 $24.8 \%$ で認められたが, グレード 3,4 については durvalumab 群 $3.4 \%$, プラセボ群 $2.6 \%$, グレード 5 はそれぞ れ 1.1, 1.7\%であり, 特に重症の肺臓炎について durvalumab 併用によるリスク上昇は認められなかった。 た だしこの試験においては, IMRTの割合や肺 V20, V5 など放射線治療内容の詳細が不明であり, 今後の実臨床 例での注意深い観察が必要であると考える，また，胸部 放射線治療後しばらく経過してから ICI 投与を行った時 に一旦落ち着いていた RP が再燃した（recall 現象）とい う症例報告 26 もり，ICI との併用には今までと異なる 反応が生じる可能性もあり, 注意を要する.

\section{多因子の組み合わせによる発症予測モデル}

前述のように多岐にわたる因子が RP 発症に関与して おり，それぞれのリスク因子単独での RP 発症の予測精 度には限界があり, 予測能向上を目指して複数の因子を 含めた発症予測モデルがいくつか報告されている.

我々は, V $20 \leqq 30 \%$ 線量制約下で CCRT を行った 122 症例を対象に, 重症 RP (グレード 3 以上) の発症と種々 の DVH 関連因子およびその他の臨床因子との相関性を 検討した. ${ }^{24} \mathrm{~V} 20$ 高值の他に, VS5 低值, 背景肺の肺線維 化（蜂巣肺）を認める場合, 高歯令の 4 因子が独立して重 症 RP の発症と相関しており，これら 4 因子に回帰係数 による重みを加味した以下に示す重症 RP の発症リスク スコアを提案した.

PRS (リスクスコア) $=3$ (if 年齢 $\geqq 68$ 歳 $)+5$ (if CT 背景肺線維化スコア $\geqq 2$ ) $+3($ if V $20 \geqq 26)+6$ (if VS5 $<1500 \mathrm{cc})$

検討した 122 例では PRS は 0〜14 (中央值 3) であり， グレード 3 以上の重症 RP の 12 か月累積発症率は PRS
が0，3〜 5，6８，9１4 でそれぞれ 0\%，7.8\%，26.6\%, $71.4 \%$ であり, 治療計画の工夫などにより PRS を 8 以下 にすることを推奨している（Figure 5).

他にも, VS5 と肺機能 $\mathrm{KCOc}$ を組み合わせる方法 27 や， 年齢・MLD・肺機能 $\mathrm{FEV}_{1.0}$ を合わせて評価するモ デル, ${ }^{28} \mathrm{DVH}$ 関連因子のみではあるがV5, V20, MLD の組み合わせによる制約モデル29なども報告されてい る。これらの評価モデルも考慮して同時性化学放射線療 法の対象患者の選択や放射線治療計画の作成を行うこと により，重症 RP の発症を抑制できる可能性がある.

\section{管理 - 治療法}

$\mathrm{RP}$ 発症を予防する薬剤として, amifostine をはじめ, ACE 阻害薬, pentoxifylline など種々の薬剤について研 究が行われてきた. 2 現在のところ, 腫瘍に対する治療効 果を減弱せずに有害事象を防ぐ, 明らかに有効とされて いる薬剤はない.

$\mathrm{RP}$ の治療法については前向き臨床試験がなく, 経験 則での治療が行われている. 症状のないグレード 1 では 基本的に治療は不要で, 経過観察となる. 軽度の症状の みのグレード 2 では無治療または鎮咳剤・気管支拡張剤 などの対症療法を行う。症状が強い場合や照射野外への 進展がみられる場合などはステロイド治療の適応とな る. 経ロプレドニゾロンを $0.5 \sim 1 \mathrm{mg} / \mathrm{kg} / \mathrm{day}$ で開始し, 症状の改善がみられれば緩徐に減量し，6〜12 週かけて 離脱する．減量中に再燃すると難治性となることが多い ため, 再燃に注意しながら緩徐に減量することが重要で ある.グレード 3 の場合もステロイド治療の適応となり, より高用量の投与や酸素投与も必要となる. グレード 4 になると他の重症間質性肺臓炎と同様に補助換気, intensive care が必要となり, azathioprine や cyclosporine などの再燃免疫抑制剂が投与されることもある.

一旦ステロイドを開始すると, 上記のように減量には 時間がかかり，減量中に再燃すると重症化するリスクが 高いため, その開始適応決定には慎重を要する. 適応判 断を決定する重要な要素が重症化の可能性判断である. 重症化するリスク因子のひとつに, 発症時期が照射終了 後早期であることが挙げられている. Sekine らは433 例の胸部放射線治療例のうち 385 例に肺障害の発症があ り,うちステロイド投与を行ったが死亡した 14 例のうち 6 週以内に単純 $X$ 線での変化を認めた症例が 11 例, 6〜 12 週が 3 例であり, 12 週以降発症例では死亡例は認めな かったと報告している. 30 また, 照射野外に広がってい くタイプの肺臓炎は重症化のリスクが高いことも知られ ている.したがってステロイド適応判断基準としては, 症状が強い場合に加えて, 症状が軽微でも照射野外に広 がる場合，発症時期が早い場合など，重症化のリスクが 
あると判断された場合も投与を検討する.

\section{まとめ}

放射線肺障害の中の急性から亜急性期に発症する RP について, 分類, 発症機序, 症状, 診断, リスク因子, 予測・予防法, 管理・治療法に関して現在までの知見を 概論した。特にリスク因子の中で放射線治療線量容積関 連因子については詳述した。今後 IMRTや定位放射線治 療など高精度放射線治療と ICI の併用が急速に普及する と思われ，治療効果の向上が期待できるとともに，有害 事象としての RP のより正確な発症予測と対策が重要課 題となり, さらなる探究が必要である. 胸部には放射線 治療を用いることにより根治が期待できる疾患も多く， $\mathrm{RP}$ をそれるあまりに根治治療の機会を逸することの ないように，適切な適応判断が求められる.

本論文内容に関連する著者の利益相反：なし

\section{REFERENCES}

1. Abratt RP, Morgan GW. Lung toxicity following chest irradiation in patients with lung cancer. Lung Cancer. 2002; 35:103-109.

2. Mehta V. Radiation pneumonitis and pulmonary fibrosis in non-small-cell lung cancer: pulmonary function, prediction, and prevention. Int J Radiat Oncol Biol Phys. 2005; 63:5-24.

3. Hanania AN, Mainwaring W, Ghebre YT, Hanania NA, Ludwig M. Radiation-Induced Lung Injury: Assessment and Management. Chest. 2019;156:150-162.

4. Tsoutsou PG, Koukourakis MI. Radiation pneumonitis and fibrosis: mechanisms underlying its pathogenesis and implications for future research. Int J Radiat Oncol Biol Phys. 2006;66:1281-1293.

5. Bledsoe TJ, Nath SK, Decker RH. Radiation Pneumonitis. Clin Chest Med. 2017;38:201-208.

6. Palma DA, Senan S, Tsujino K, Barriger RB, Rengan R, Moreno $\mathrm{M}$, et al. Predicting radiation pneumonitis after chemoradiation therapy for lung cancer: an international individual patient data meta-analysis. Int J Radiat Oncol Biol Phys. 2013;85:444-450.

7. Emami B, Lyman J, Brown A, Coia L, Goitein M, Munzenrider JE, et al. Tolerance of normal tissue to therapeutic irradiation. Int J Radiat Oncol Biol Phys. 1991; 21:109-122.

8. Graham MV, Purdy JA, Emami B, Harms W, Bosch W, Lockett MA, et al. Clinical dose-volume histogram analysis for pneumonitis after 3D treatment for non-small cell lung cancer (NSCLC). Int J Radiat Oncol Biol Phys. 1999;45: 323-329.

9. Tsujino K, Hirota S, Endo M, Obayashi K, Kotani Y, Satouchi M, et al. Predictive value of dose-volume histogram parameters for predicting radiation pneumonitis after concurrent chemoradiation for lung cancer. Int $J$ Radiat Oncol Biol Phys. 2003;55:110-115.
10. Marks LB, Bentzen SM, Deasy JO, Kong FM, Bradley JD, Vogelius IS, et al. Radiation dose-volume effects in the lung. Int J Radiat Oncol Biol Phys. 2010;76(Suppl):S70S76.

11. Sasaki T, Seto T, Yamanaka T, Kunitake N, Shimizu J, Kodaira T, et al. A randomised phase II trial of S-1 plus cisplatin versus vinorelbine plus cisplatin with concurrent thoracic radiotherapy for unresectable, locally advanced non-small cell lung cancer: WJOG5008L. Br J Cancer. 2018;119:675-682.

12. Yom SS, Liao Z, Liu HH, Tucker SL, Hu CS, Wei X, et al. Initial evaluation of treatment-related pneumonitis in advanced-stage non-small-cell lung cancer patients treated with concurrent chemotherapy and intensitymodulated radiotherapy. Int J Radiat Oncol Biol Phys. 2007; 68:94-102.

13. Wang SL, Liao Z, Vaporciyan AA, Tucker SL, Liu H, Wei $\mathrm{X}$, et al. Investigation of clinical and dosimetric factors associated with postoperative pulmonary complications in esophageal cancer patients treated with concurrent chemoradiotherapy followed by surgery. Int J Radiat Oncol Biol Phys. 2006;64:692-699.

14. Chen J, Hong J, Zou X, Lv W, Guo F, Hong H, et al. Association between absolute volumes of lung spared from low-dose irradiation and radiation-induced lung injury after intensity-modulated radiotherapy in lung cancer: a retrospective analysis. J Radiat Res. 2015;56:883-888.

15. Tsujino K, Hirota S, Kotani Y, Kado T, Yoden E, Fujii O, et al. Radiation pneumonitis following concurrent accelerated hyperfractionated radiotherapy and chemotherapy for limited-stage small-cell lung cancer: Dose-volume histogram analysis and comparison with conventional chemoradiation. Int J Radiat Oncol Biol Phys. 2006;64:11001105.

16. Semenenko VA, Molthen RC, Li C, Morrow NV, Li R, Ghosh SN, et al. Irradiation of varying volumes of rat lung to same mean lung dose: a little to a lot or a lot to a little? Int J Radiat Oncol Biol Phys. 2008;71:838-847.

17. Aibe N, Yamazaki H, Nakamura S, Tsubokura T, Kobayashi K, Kodani N, et al. Outcome and toxicity of stereotactic body radiotherapy with helical tomotherapy for inoperable lung tumor: analysis of Grade 5 radiation pneumonitis. J Radiat Res. 2014;55:575-582.

18. Chun SG, Hu C, Choy H, Komaki RU, Timmerman RD, Schild SE, et al. Impact of Intensity-Modulated Radiation Therapy Technique for Locally Advanced Non-SmallCell Lung Cancer: A Secondary Analysis of the NRG Oncology RTOG 0617 Randomized Clinical Trial. J Clin Oncol. 2017;35:56-62.

19. Liao Z, Lee JJ, Komaki R, Gomez DR, O’Reilly MS, Fossella FV, et al. Bayesian Adaptive Randomization Trial of Passive Scattering Proton Therapy and Intensity-Modulated Photon Radiotherapy for Locally Advanced Non-Small-Cell Lung Cancer. J Clin Oncol. 2018;36:1813-1822.

20. Vogelius IR, Bentzen SM. A literature-based metaanalysis of clinical risk factors for development of radiation induced pneumonitis. Acta Oncol. 2012;51:975-983.

21. Kong FM, Wang S. Nondosimetric risk factors for 
radiation-induced lung toxicity. Semin Radiat Oncol. 2015; 25:100-109.

22. Zhao L, Wang L, Ji W, Wang X, Zhu X, Hayman JA, et al. Elevation of plasma TGF-betal during radiation therapy predicts radiation-induced lung toxicity in patients with non-small-cell lung cancer: a combined analysis from Beijing and Michigan. Int J Radiat Oncol Biol Phys. 2009;74: 1385-1390.

23. Sanuki N, Ono A, Komatsu E, Kamei N, Akamine S, Yamazaki T, et al. Association of computed tomographydetected pulmonary interstitial changes with severe radiation pneumonitis for patients treated with thoracic radiotherapy. J Radiat Res. 2012;53:110-116.

24. Tsujino K, Hashimoto T, Shimada T, Yoden E, Fujii O, Ota Y, et al. Combined analysis of V20, VS5, pulmonary fibrosis score on baseline computed tomography, and patient age improves prediction of severe radiation pneumonitis after concurrent chemoradiotherapy for locally advanced non-small-cell lung cancer. J Thorac Oncol. 2014; 9:983-990.

25. Antonia SJ, Villegas A, Daniel D, Vicente D, Murakami S, Hui R, et al. Durvalumab after Chemoradiotherapy in Stage III Non-Small-Cell Lung Cancer. N Engl J Med. 2017;
377:1919-1929.

26. Shibaki R, Akamatsu H, Fujimoto M, Koh Y, Yamamoto $\mathrm{N}$. Nivolumab induced radiation recall pneumonitis after two years of radiotherapy. Ann Oncol. 2017;28:1404-1405.

27. Jenkins P, Watts J. An improved model for predicting radiation pneumonitis incorporating clinical and dosimetric variables. Int J Radiat Oncol Biol Phys. 2011;80: 1023-1029.

28. Wang J, Cao J, Yuan S, Ji W, Arenberg D, Dai J, et al. Poor baseline pulmonary function may not increase the risk of radiation-induced lung toxicity. Int J Radiat Oncol Biol Phys. 2013;85:798-804.

29. Khalil AA, Hoffmann L, Moeller DS, Farr KP, Knap MM. New dose constraint reduces radiation-induced fatal pneumonitis in locally advanced non-small cell lung cancer patients treated with intensity-modulated radiotherapy. Acta Oncol. 2015;54:1343-1349.

30. Sekine I, Sumi M, Ito Y, Nokihara H, Yamamoto N, Kunitoh $\mathrm{H}$, et al. Retrospective analysis of steroid therapy for radiation-induced lung injury in lung cancer patients. Radiother Oncol. 2006;80:93-97. 